\title{
Faunal community change in the sediment impacted Bovington Stream and the River Frome (Dorset, UK) between 1998 and 2016
}

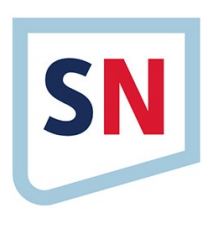

\author{
Patrick D. Armitage ${ }^{1}$ (D) John F. Murphy ${ }^{2}$. James L. Pretty ${ }^{2} \cdot$ John Davy-Bowker $^{1} \cdot$ Gloria Tapia $^{1} \cdot$ Amanda Arnold $^{2}$. \\ J. Iwan Jones ${ }^{2}$
}

Received: 31 March 2020 / Accepted: 19 October 2020 / Published online: 28 October 2020

(c) Springer Nature Switzerland AG 2020

\begin{abstract}
Bovington Camp has been a main training area for armoured vehicles since 1916. Over the years, this has resulted in the erosion and mobilisation of soil particles into watercourses draining the area. Sediment-rich water from a main tributary, the Bovington Stream, discolours the River Frome during high flows. Regulatory agencies and angling groups were concerned that the quality of the river was being affected by run-off from the military ranges. Macroinvertebrate communities were studied between 1998 and 2016 at two sites on the Bovington Stream above and below a sediment trapping pond and two sites on the River Frome above and below the confluence. Samples were collected in Spring and Autumn and ecological quality was assessed using the River Invertebrate Classification Tool (RICT). There were marked increases in the ecological quality of the Bovington sites over time with most change occurring in the period 1998 to 2004. The two Frome sites were consistently classed as high quality throughout the study period. Increases in taxon richness between 1998-2004 and 2011-2016 were significant in the Bovington Stream but no change was observed in the River Frome. Faunal abundance at all sites fluctuated but there were no significant trends. The Combined Fine Sediment Index (CoFSI), assesses the impact of fine sediment pressure on the macroinvertebrate community. Low CoFSI scores were recorded in the early years of the study (1998-2000) at both Bovington sites but showed a steady increase until around 2010-2011, suggesting a degree of improvement/recovery from fine sediment pressure. No similar changes in CoFSI scores occurred in the River Frome. In the absence of any major disturbances in the Bovington catchment other than sediment remediation we conclude that the observed 'improvements' in the Bovington Stream are in large part due to the sediment control measures (sediment trapping and diversion) implemented since 1998. The project has shown how relatively simple sediment control strategies can improve ecological quality and has provided information on long-term faunal responses which can help managers plan the extent and timing of effective mitigation measures.
\end{abstract}

Keywords Long-term observations · Freshwater macroinvertebrates · Streams · Rivers · Sediment management

\section{Introduction}

Sediment is an integral part of healthy, functioning river ecosystems. A natural hydrological regime in conjunction with bed sediment and riparian vegetation contribute to physical habitat diversity, creating a mosaic of habitats which support a diverse range of biota. Spatial heterogeneity is driven by periodic and random variations in discharge and sediment erosion and supply [1, 2]. When natural levels of sediment supply are exceeded, (in particular, fine sediment; here defined as inorganic and organic particles of less than $2 \mathrm{~mm}$ in diameter) both ecosystem processes and water resource management are threatened. Globally, increased fine sediment loading to

Patrick D. Armitage, parmitage@fba.org.uk| ${ }^{1}$ Freshwater Biological Association, River Laboratory, East Stoke, Wareham, Dorset BH20 6BB, UK. ${ }^{2}$ School of Biological and Chemical Sciences, Queen Mary University of London, London E1 4NS, UK. 
rivers has been mainly caused by agricultural intensification [3-6], but mining and catchment disturbance [7-10], deforestation [11], flow regulation [12] and urban development [13] also contribute to the problem. Excess fine sediment is now recognised as an ubiquitous and harmful form of pollution causing ecological degradation of river ecosystems $[14,15]$.

In the UK most excess fine sediment arises from agricultural intensification [16-18]. The effects of increased sediment loading on benthic macroinvertebrates can include, abrasion, clogging of interstitial spaces in the substratum, burial, lowered oxygen concentration and changes to food availability and quality [15]. The combination of effects may lead to changes in the faunal composition with direct and indirect consequences for food web structure.

Attempts to control these problems include several measures and guidelines [19-22] designed initially to prevent erosion of soil in the catchment and if this fails, to intercept or divert sediment from entering water courses. Despite numerous case studies from around the world where different interventions have been applied to control sediment, the authors are unaware of any published data detailing long-term (>10 years) macroinvertebrate community change in sediment-managed catchments. There are several long-term studies on other factors affecting streams such as restoration [23], acidification [24], and climate change [25-28] but sediment has generally been overlooked. An exception is work in the Coweeta Catchment [29] which reports on 30 years of observations but with minimal reference to faunal community change.

In this study we use benthic macroinvertebrate community data to monitor the water quality and ecological health of a sediment- impacted stream and its effect on a receiving river. The original one-off survey in 1998 was to establish the environmental quality of the two water courses and assess whether sediment inputs were affecting benthic fauna in the receiving river. Repeated monitoring has over the past 19 years produced a record of community change in a stream where sediment inputs have been managed, both in the upper catchment and in the lower reaches of the stream. This unique long-term dataset provides an opportunity to examine temporal trends in macroinvertebrate faunal communities and assess the effects of sediment control measures on these communities over an extended period. To this end we ask two questions (1) Has sediment input affected the faunal community of the receiving stream? and (2) Have the sediment control measures been effective over the 19-year period?

\section{Material and methods}

\subsection{Study area}

In June 1916 Bovington Camp was established by the British Army as a training area for the Heavy Branch Machine Gun Corps and subsequently became the location from which most Tank Corps units were raised during the First World War. Armoured vehicles have been used extensively at Bovington since the conception of the first tank and the area remains a main Army training area.

The majority of the Bovington tank training area is situated on elevated land at Wool Heath overlooking the River Frome floodplain. Geologically the area is part of the Palaeogene (Tertiary) Wareham Basin comprising sands, clays and gravels originally covered by heathland vegetation, now very eroded. The catchment area of the Bovington Stream is about $6 \mathrm{~km}^{2}$ of which about a third is heathland, where the tank training takes place. The remaining two thirds comprise an urban section (the Army Camp) and a wooded and pastoral region in the lower reaches of the catchment. Streams draining the area have relatively steep slopes (about $19 \mathrm{~m}$ per $\mathrm{km}$ ) and water draining the eroded catchment entrains sediment and clay from the exposed stream bed which eventually flow into the Bovington Stream and on into the River Frome; a chalk stream draining an area of $660 \mathrm{~km}^{2}$.

Anecdotal evidence suggests that siltation in Bovington Stream has been a problem since at least 1966 and despite measures undertaken between 1985 and 1988 including regular desilting of a check dam in the upper catchment and diversion of water onto vegetated areas allowing natural filtration to take place, the problem continued. Subsequently, further management measures were undertaken which included the construction of a tarmac track for basic driving exercises which reduced pressure on the heathland and a series of silt traps on feeders into the stream. Following a severe sediment episode in 1994 [30], the MOD embarked on a series of further management measures including more check dams and silt traps in the upper catchment, and the creation of a diversion channel and pond which would, at times of high flow, divert the majority of the water along a channel flowing into a newly created wetland and settlement pond (Fig. 1).

As a result of these latter activities in the lower catchment, an estimated 200-300 tons sediment were deposited on the land adjacent to the stream within a 3-month period (Environment Agency pers. comm). Despite this, sediment transported by the stream at periods of high flow still causes discolouration in the receiving waters of the River Frome [31]. While this was readily apparent, it was not clear what the effects were on benthic 


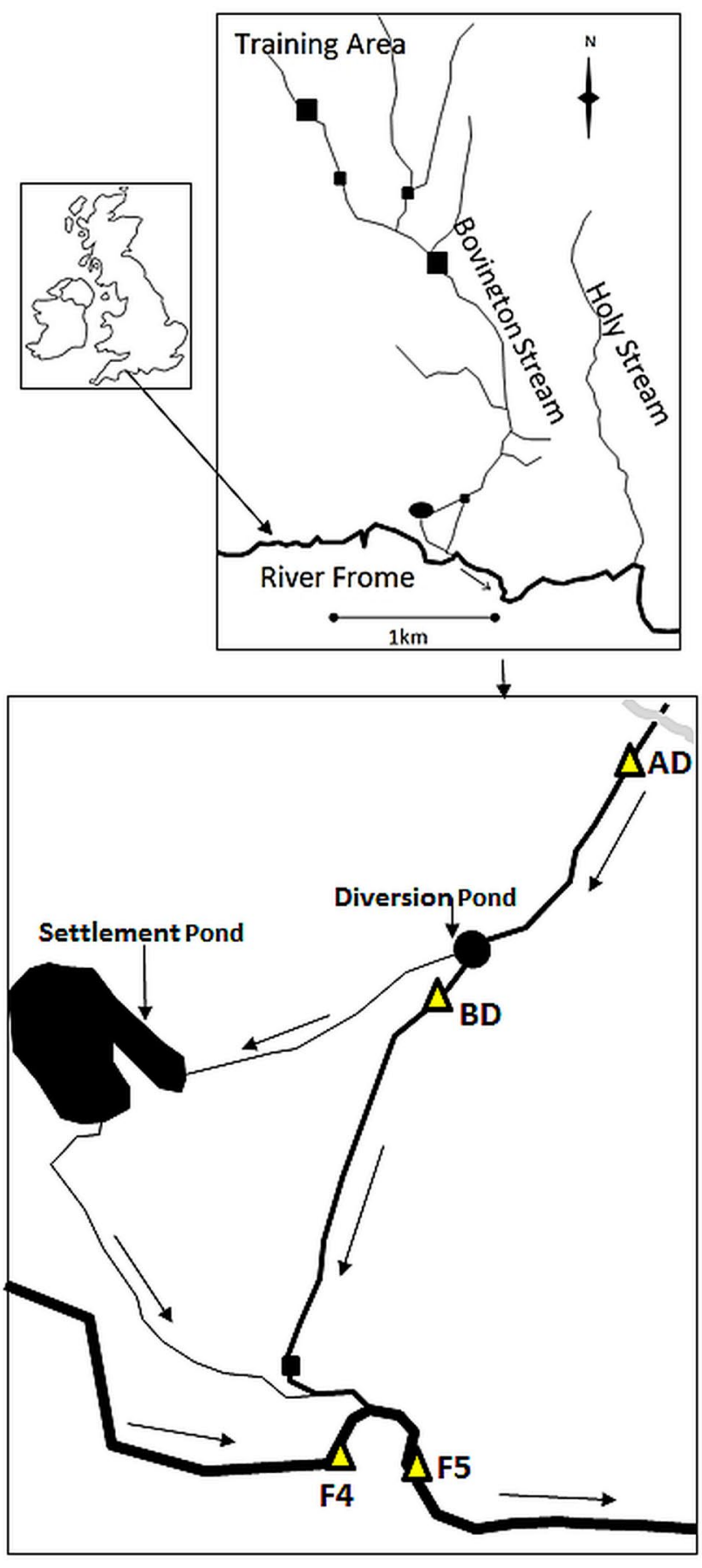

Fig. 1 Sketch map showing location of the Bovington Stream catchment and sample sites (triangles) together with the position of check dams (filled squares) in the upper catchment

macroinvertebrates and in 1998 the MOD funded a project, initially for one year, to monitor the effects of the new diversion channel and other management measures on the macroinvertebrate fauna of Bovington Stream and the River Frome.

\subsection{Sampling programme}

After a preliminary survey, four sites were chosen above $(\mathrm{AD})$ and below $(\mathrm{BD})$ the proposed construction of a diversion pond and above (F4) and below (F5) the confluence of the stream with the main River Frome (Fig. 1). At AD and $\mathrm{BD}$, the stream is about $2 \mathrm{~m}$ wide with a bed consisting of sand overlain with an armour layer of gravel and pebbles (Table 1). Dense shade prevents macrophyte development in both sites. Bovington Stream flows into the lower reaches of the River Frome about $40 \mathrm{~km}$ from its source. At this point the river is about $12 \mathrm{~m}$ wide and supports dense beds of macrophytes. Summary site features are provided in Table 1.

Macroinvertebrate samples were collected in spring (March-May) and autumn (September-November) between 1998 and 2016, using a standard 3-min kick/ sweep technique with a $900 \mu \mathrm{m}$ mesh pond net [32]. Samples were fixed in $5 \%$ formaldehyde solution and returned to the laboratory where invertebrates were identified to the lowest practicable taxonomic level. Oligochaeta were identified as such, Sphaeriidae to genus, Chironomidae to sub-family and tribe level and the remaining fauna to species level where keys and life-history stage allowed. Assessment of substratum conditions was carried out by visual inspection and recording the percentage cover of bedrock, boulders, pebbles and gravel, sand, silt and clay and macrophyte cover [32].

\subsection{Physicochemical variables}

Width, depth and velocity were measured on each sampling occasion at a quarter, half and three-quarter distance along a transect across the channel in both Bovington Stream and the River Frome. No continuous discharge data were available for Bovington Stream; therefore the width, depth and velocity measurements were used to calculate spot estimates of discharge. Additional discharge data for the Frome were obtained from the Environment Agency. Chemical data were made available from the Environment Agency [33] and from the Lowland Catchment Research programme [34]. These data show that the Bovington Stream is a nutrient poor, low alkalinity, circumneutral heathland stream with a highly variable discharge regime $\left(0.01-0.19 \mathrm{~m}^{3} \mathrm{~s}^{-1}\right)$ and turbid waters (mean suspended sediment concentration $47 \mathrm{mg} \mathrm{I}^{-1}$ ). The Frome in contrast is a nutrient-rich, high alkalinity, chalk river with a more stable discharge regime and low turbidity (mean suspended sediment concentration $10 \mathrm{mg} \mathrm{l}^{-1}$ ). 
Table 1 Mean values (+ standard deviation) of physical features recorded at time of sampling in the Bovington Stream (sites AD and BD) and the River Frome (F4 and F5)

\begin{tabular}{lllll}
\hline & AD & BD & F4 & F5 \\
\hline Altitude (m O.D.) & 18 & 16 & 15 & 15 \\
Slope m/km & 10 & 10 & 16 & 16 \\
Distance from source (km) & 2.5 & 2.8 & 40 & 40.3 \\
Width (m) & $2.28 \pm 0.26$ & $1.58 \pm 0.33$ & $12.07 \pm 2.08$ & $11.31 \pm 2.26$ \\
Depth (cm) & $11 \pm 5$ & $8 \pm 3$ & $92 \pm 53$ & $67 \pm 17$ \\
Velocity (category) & $2.59 \pm 0.50$ & $2.66 \pm 0.48$ & $3.11 \pm 0.53$ & $3.63 \pm 0.65$ \\
Boulders/cobbles (\% cover) & $13 \pm 12.42$ & $17 \pm 18.21$ & $3 \pm 5.28$ & $7 \pm 9.09$ \\
Pebbles/gravel (\% cover & $68 \pm 14.95$ & $63 \pm 23.87$ & $68 \pm 23.87$ & $74 \pm 16.68$ \\
Sand (\%cover) & $16 \pm 9.18$ & $13 \pm 11.67$ & $20 \pm 10.24$ & $16 \pm 9.87$ \\
Silt/clay (\% cover) & $3 \pm 3.47$ & $7 \pm 10.19$ & $9 \pm 11.5$ & $3 \pm 6.96$ \\
Q (m3/s) & $0.05 \pm 0.05$ & $0.04 \pm 0.02$ & $4.48 \pm 0.18$ & $4.62 \pm 0.12$ \\
Suspended solids mg/l & $75.31 \pm 83.38$ & & $20.00 \pm 28.10$ & \\
Nitrate mg/l NO 3 & $2.96 \pm 0.98$ & & $24.38 \pm 3.36$ & \\
P sOL reactive mg/l P & $0.04 \pm 0.02$ & & $0.09 \pm 0.03$ & \\
Ammoniacal nitrogen mg/l N & $0.08 \pm 0.03$ & & $0.07 \pm 0.03$ & \\
pH value & $7.57 \pm 0.15$ & & $8.16 \pm 0.14$ & \\
Conductivity at 20 ${ }^{\circ} \mathrm{C} \mu \mathrm{S} / \mathrm{cm}$ & $207.58 \pm 44.21$ & & $475.78 \pm 33.27$ & \\
Alkalinity as CaCO ${ }_{3}$ & $58.97 \pm 11.45$ & & $197.29 \pm 22.72$ & \\
\hline
\end{tabular}

Also shown are mean values of chemical data extracted from [30] for the period 2003-2005 (112 samples from the River Frome at East Stoke and 55 samples from the Bovington Stream just upstream of site $\mathrm{BD}$

\subsection{Macroinvertebrate community analysis}

We used the Mann Kendall test to identify monotonic trends in macroinvertebrate abundance and taxon richness over time at each site [35]. Initial exploratory analyses of the faunal community data to identify patterns of change across sites and time were undertaken using hierarchical clustering and non-metric multidimensional scaling (NMDS) ordination based on a matrix of Bray-Cutis similarity values calculated between all samples collected at the four sites over the 19 years. Abundance data were first normalised by fourth-root transformation to reduce the influence of dominant species. Two samples taken in 2011 at the upstream River Frome site (F4) were omitted from the analyses due to departure from the normal processing protocol. The reliability of the NMDS is given by the stress value which indicates how faithfully the relationships among samples are represented in the twodimensional ordination plot. Stress values $<0.05$ indicate excellent representation but a value of $<0.2$ still gives a potentially useful 2-D picture [36]. Analysis of Similarity (ANOSIM) is a non-parametric permutation procedure applied to the similarity matrix that computes a test statistic $R$ that reflects the differences between groups of sites relative to differences within groups of sites. It was used to determine if any year groupings suggested by cluster analysis were statistically different. $R$ values give an absolute measure of how separated the groups are on a scale of 0 (indistinguishable) to 1 (all similarities within groups are less than any similarity between groups) [36]. The significance of differences in abundance of taxa between year groups was examined with Student t-tests.

Mann-Kendall tests were carried out using the Kendall package [37] in R 3.6.1 [38]. Hierarchical clustering was carried out using the Community Analysis Package (Pisces Conservation Ltd). ANOSIM, and NMDS were performed using Primer v 5 [36]. Correspondence Analysis (CCA) in the analysis package ECOM II (Pisces Conservation Ltd) was used to examine the relationship between the biological matrix and the suite of environmental variables at each site.

\subsection{Ecological quality assessment}

In the UK, the ecological condition of watercourses is determined by the regulatory authorities (The Environment Agency, Natural Resources Wales, the Scottish Environment Protection Agency and the Northern Ireland Environment Agency) using the River Invertebrate Classification Tool (RICT) [39]. RICT generates a prediction of the macroinvertebrate community you would expect to find at a site in the absence of any pollution. This can then be compared with the fauna observed at the site being assessed and the extent of difference between the predicted and observed fauna provides a measure of the ecological condition of the site. The macroinvertebrate 
community is described in terms of the number of taxa (NTaxa) observed in the sample, and the Average Score Per Taxon (ASPT). The ASPT index gives a score for each taxon related to its sensitivity to organic pollution (with more sensitive taxa having higher scores). The average of the scores for all taxa present at a site gives the final ASPT index value. The assessment is based on the combined data from a spring and autumn sample from a site in one year. Observed scores for NTaxa and ASPT are divided by RICT-predicted scores, giving an ecological quality ratio (EQR). EQR ranges in value from 1 or greater than 1 (meaning that the macroinvertebrate fauna found at a site has reached or exceed expectations compared to reference sites of high ecological quality), to close to zero, where the observed fauna falls far below that expected of an unstressed site of the same physical and chemical nature. A further refinement is the banding of EQRs into five quality classes (High, Good, Moderate, Poor, Bad), allowing rivers to be classified in a standard manner across the whole of the UK. Water courses of moderate or worse quality are considered to be failing on ecological quality and, hence, requiring mitigation/management to improve ecological status. A site's overall classification is given by the lower of the NTAXA and ASPT classes (Table 2).

\subsection{Impact of fine sediment}

In addition to the RICT assessment of ecological quality, all data from 1998 to 2016 were analysed using the Combined Fine Sediment Index (CoFSI), which assesses the impact of fine sediment pressure on the macroinvertebrate community [40]. The index assigns a score from 1 to 10 to taxa according to their sensitivity to the organic content and quantity of fine sediment in the stream bed, with highly sensitive taxa scoring 10 and highly tolerant taxa scoring 1. The final CoFSI value for a site is, like ASPT, the average of the scores for the taxa observed and can vary from about 3.5- 6 across sites in the UK, with higher values indicating less fine sediment stress on the community at that site (see [40] for more details).

Table 2 Ecological Quality Ratios of ASPT and NTaxa corresponding to the five quality classes

\begin{tabular}{lll}
\hline & EQR ASPT & EQR NTaxa \\
\hline High & $>0.97$ & $>0.85$ \\
Good & $0.86-0.97$ & $0.71-0.85$ \\
Moderate & $0.75-0.86$ & $0.57-0.71$ \\
Poor & $0.63-0.75$ & $0.47-0.57$ \\
Bad & $<0.63$ & $<0.47$ \\
\hline
\end{tabular}

\section{Results}

\subsection{Benthic macroinvertebrates}

A total of 218 taxa were recorded from the 138 samples collected in spring and autumn over the period 1998 to 2016 with $111,117,159$ and 157 taxa occurring respectively at sites $A D, B D, F 4$ and F5. The fauna in Bovington Stream was dominated numerically by Oligochaeta (11\%), Potamopyrgus antipodarum (Mollusca) (33\%), Gammarus pulex (Crustacea) (16\%) and Elmidae (Coleoptera) (17\%) which together comprised $77 \%$ of the total community composition. In the Frome, Oligochaeta (27\%), G. pulex (24\%), Orthocladiinae (Diptera) (11\%) and Brachycentrus subnubilus (6\%), Ithytrichia, (1\%) and Hydropsyche pellucidula (1\%) (all trichopterans), comprised $70 \%$ of the total community composition. The number of taxa recorded in the Bovington Stream over this period significantly increased at both sites (AD: Kendall $\mathrm{\tau}=0.402, P=0.001, \mathrm{BD}$ : Kendall $\tau=0.487, P=0.001)$. Over the same period there was no statistically significant change in the numbers of taxa recorded at the two Frome sites. Total abundance at all sites also showed no statistically significant changes over the study period (Fig. 2).

\subsection{Community changes}

The initial exploratory cluster analyses identified three distinct groupings for the Bovington Stream. These approximately six-year periods were superimposed on subsequent NMDS plots for all sites and the distinctness of the groupings assessed using ANOSIM. The macroinvertebrate community in both Bovington Stream sites showed a clear temporal pattern with samples collected before 2005 (Year Group 1) being differentiated from the others along the first axis of the ordination plots (Fig. 3). At both Bovington Stream sites, there was a weaker distinction between 2005 and 2010 samples (Year Group 2) and 2011-2016 samples (Year Group 3), with the difference being defined primarily along the second axis or a combination of both axes (Fig. 3). For the Frome sites no such temporal separation was apparent (Fig. 3).

There were significant differences between year groupings at both Bovington sites (Table 3). Subsequent pairwise tests showed that the greatest differences between year groups occurred between the first and last periods, and to a lesser extent between the first and second periods (Fig. 3; Table 3). The three-year groupings were barely separable in the Frome sites although some taxa showed significant differences in abundance between year groups (Fig. 3; Table 3). However, inter-season differences (Spring 

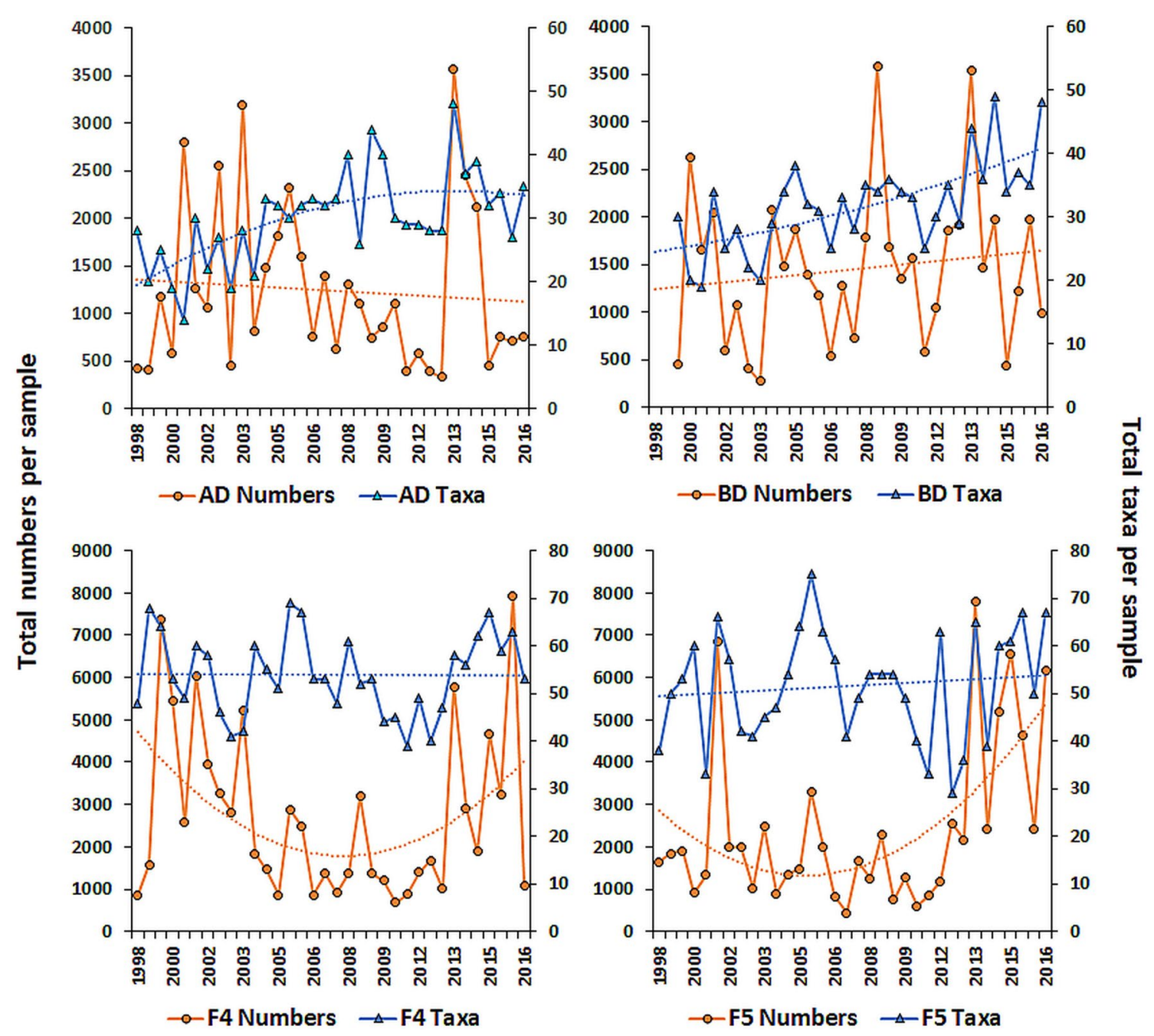

Fig. 2 The numbers of taxa and total abundance per sample in the Bovington Stream (AD and BD) and the River Frome (F4 and F5) together with trend lines over the 19-year period

vs Autumn) were more pronounced in the Frome than in the Bovington Stream (Table 3).

Taxa showing significant changes in abundance in Bovington Stream between Year Groups 1 and 3 are listed in Table 4. Differing abundances of 11 taxa were observed between year groups and between sites. At site AD, Baetis rhodani, Limnius volckmari, Elmis aenea and two caddis species (Sericostoma personatum and Silo pallipes) were more abundant in Year Group 3. At site BD, B. rhodani, E. aenea, and S. pallipes were also more abundant in Year Group 3 together with G. pulex, Hydropsyche siltalai and Polycelis felina. At site AD, Ancylus fluviatilis and Hydropsyche angustipennis were more abundant in Year Group 1 as was Asellus aquaticus at BD. Comparing Year Group 3 at the two sites A. fluviatilis, G. pulex, L. volckmari, E. aenea, $B$. rhodani and S. pallipes all were more abundant at BD. (Appendix A lists taxa comprising $>0.5 \%$ of the total fauna in the Bovington Stream and River Frome in all year groups).

Six variables (width, depth, velocity, discharge, \% cover of sand and year of study) were used in a canonical correspondence analysis, to examine the relationship between variation in the biological community and environmental conditions at each site. Most variance was explained by 'year' $15 \%$ and $16 \%$ in AD and BD and $7 \%$ and $19 \%$ in $\mathrm{F} 4$ and $\mathrm{F} 5$, respectively). However, low eigenvalues for the canonical axes indicate that the environmental variables used in the analyses do not adequately explain community structure. We have insufficient robust environmental data collected at an adequate temporal resolution to be able to attribute causes properly, directly and confidently to the changes we find in Bovington Stream macroinvertebrate community. 

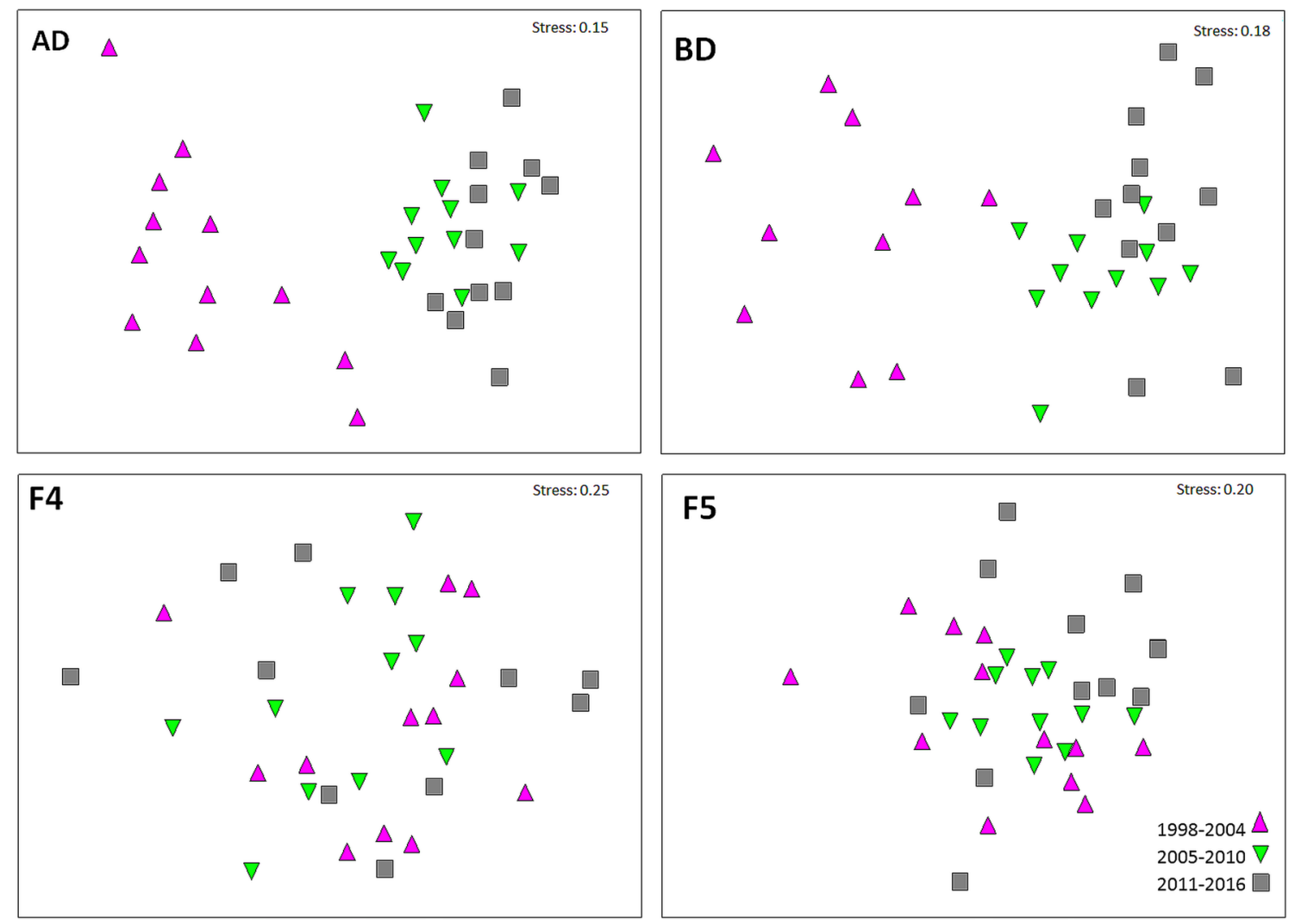

Fig. 3 Non-Metric-Multidimensional-Scaling analysis of benthic communities between year groups at sites on the Bovington Stream (AD and $\mathrm{BD}$ ) and River Frome (F4 and F5)

\subsection{Ecological quality assessment}

The two Frome sites have been consistently classed as high quality throughout the study period (Fig. 4a), both in terms of the EQRs for ASPT (Fig. 4b) and NTaxa (Fig. 4c). This suggests that there is no discernible difference in the ecological quality of sites immediately upstream and downstream of the Bovington Stream confluence and that the Bovington Stream is not having a marked impact on the Frome.

For the Bovington Stream, there is evidence that both sites have improved in ecological quality over the duration of the study (Fig. 4a). In terms of the EQR for ASPT, sites $A D$ and $B D$ tended towards the moderate quality class from 1998 to 2001, but since 2002 they have been classed consistently as good or high quality (Fig. 4b). The EQR for NTaxa at sites AD and BD showed a similar improvement in ecological quality by 2004 , although the pattern was a little more variable (Fig. 4c).

\subsection{Impact of fine sediment}

Throughout the study, the sites on the River Frome have returned consistent CoFSI scores, fluctuating between
4.2 and 4.8 (Fig. 5), suggesting no directional change in deposited sediment in the Frome over the study period. In the early years of the study (1998-2000) sites AD and BD returned relatively low CoFSI scores (3.9-4.1) but, site $A D$ showed a steady increase in CoFSI scores until 2010-2011 and has maintained consistent CoFSI scores of 4.4-4.5 since that time, suggesting a degree of improvement/ recovery from fine sediment pressure. Initial improvements at BD appeared to peak around 2008 (4.5-4.6), after which they have steadily declined to levels last seen in 2002-2003. BD no longer experiences high flows due to the presence of the diversion pond and dam (Fig. 5).

\section{Discussion}

\subsection{Fauna and quality assessment}

The prime aim of this project was to determine whether the outflow from the sediment-rich Bovington Stream was affecting the quality of the receiving River Frome. We have shown that over the 19-year period the environmental quality, has improved in the Bovington Stream sites and remained consistently'High' in the River Frome. During this 
Table 3 Results from ANOSIM analyses of between Year Group faunal community differences at sites on the Bovington Stream (AD and $\mathrm{BD}$ ) and the River Frome (F4 and F5)

\begin{tabular}{|c|c|c|c|c|c|}
\hline Site & Global R & S \% & Year groups & Pairwise R & S \% \\
\hline \multirow[t]{3}{*}{$A D$} & 0.595 & 0.1 & $1-2$ & 0.765 & 0.1 \\
\hline & & & $1-3$ & 0.836 & 0.1 \\
\hline & & & $2-3$ & 0.339 & 0.1 \\
\hline \multirow[t]{3}{*}{ BD } & 0.618 & 0.1 & $1-2$ & 0.789 & 0.1 \\
\hline & & & $1-3$ & 0.88 & 0.1 \\
\hline & & & $2-3$ & 0.346 & 0.1 \\
\hline \multirow[t]{3}{*}{$A D$ vs $B D$} & 0.358 & 0.1 & AD1-BD1 & 0.115 & 5.9 \\
\hline & & & AD3-BD3 & 0.264 & 0.2 \\
\hline & & & AD-BD & 0.132 & 2 \\
\hline \multirow[t]{3}{*}{ F4 } & 0.325 & 0.1 & $1-2$ & 0.199 & 0.7 \\
\hline & & & $1-3$ & 0.365 & 0.1 \\
\hline & & & $2-3$ & 0.431 & 0.1 \\
\hline \multirow[t]{3}{*}{ F5 } & 0.262 & 0.1 & $1-2$ & 0.22 & 0.4 \\
\hline & & & $1-3$ & 0.302 & 0.1 \\
\hline & & & $2-3$ & 0.3 & 0.1 \\
\hline \multirow[t]{3}{*}{ F4 vs F5 } & 0.358 & 0.1 & F41-F51 & 0.219 & 0.4 \\
\hline & & & F43-F53 & 0.055 & 16 \\
\hline & & & F4-F5 & 0.223 & 0.1 \\
\hline Inter season & Global R & S \% & & & \\
\hline$A D$ & 0.142 & 1.2 & & & \\
\hline BD & 0.06 & 8.3 & & & \\
\hline F4 & 0.421 & 0.1 & & & \\
\hline F5 & 0.368 & 0.1 & & & \\
\hline
\end{tabular}

Year Groups: 1 1998-2004; 2 2005-2010; 3 2011-2016; see text for details

period, the MOD continued their maintenance of the sediment management structures in the catchment.

In Bovington Stream, the site AD only experienced silt management activities in the upper catchment. However, at site BD the stream was also influenced by the diversion pond and dam which deflected high flows to a settlement pond and wetland. Thus, the fauna at site BD experienced lower discharges, and as evidenced by the need to desilt the diversion pond on two occasions within the 19-year period of study, a decrease in sediment being delivered from upstream. Tocher [41] noted that during high discharges in Bovington Stream the bulk of the sediment load was funnelled into the diversion channel and thence to the settlement pond. Frequently stream beds erode below dams [42] but there was no evidence of this at site $\mathrm{BD}$ and the channel and bed structure were unaltered in the 19-year period.

The problems associated with sediment pollution in many stream systems arising from agriculture, urbanisation, mining, and forestry are absent from Bovington Stream. The disturbed catchment is not agricultural [43], urbanised [44], mined or densely forested $[11,45]$ and
Table 4 Taxa showing significant differences in abundance between year group 1 and year group 3 in the Bovington Stream $(A D$ and $B D)$ and the River Frome (F4 and F5) together with taxa showing significant differences in abundance between sites in year group 3

\begin{tabular}{|c|c|c|c|c|}
\hline Taxa & AD1 & AD3 & P 2tail & Result \\
\hline Baetis rhodani & 1.00 & 21.82 & 0.016 & $A D 3>A D 1$ \\
\hline Ancylus fluviatilis & 43.73 & 12.73 & 0.009 & $A D 1>A D 3$ \\
\hline Hydropsyche angustipennis & 52.18 & 6.45 & 0.037 & $\mathrm{AD} 1>\mathrm{AD} 3$ \\
\hline Limnius volckmari & 36.18 & 114.00 & 0.008 & $\mathrm{AD} 3>\mathrm{AD} 1$ \\
\hline Elmis aenea & 2.45 & 80.64 & 0.003 & $\mathrm{AD} 3>\mathrm{AD} 1$ \\
\hline Sericostoma personatum & 0.00 & 1.09 & 0.038 & $A D 3>A D 1$ \\
\hline \multirow[t]{2}{*}{ Silo pallipes } & 0.00 & 13.00 & 0.004 & $A D 3>A D 1$ \\
\hline & AD3 & BD3 & & \\
\hline Ancylus fluviatilis & 12.73 & 37.00 & 0.052 & $\mathrm{AD} 3>\mathrm{BD} 3$ \\
\hline Limnius volckmari & 114.00 & 212.00 & 0.003 & $\mathrm{AD} 3>\mathrm{BD} 3$ \\
\hline Elmis aenea & 80.64 & 185.91 & 0.045 & $\mathrm{AD} 3>\mathrm{BD} 3$ \\
\hline \multirow[t]{2}{*}{ Gammarus pulex } & 180.09 & 365.45 & 0.004 & $\mathrm{AD} 3>\mathrm{BD} 3$ \\
\hline & BD1 & BD3 & & \\
\hline Baetis rhodani & 4.90 & 33.10 & 0.010 & $\mathrm{BD} 3>\mathrm{BD} 1$ \\
\hline Elmis aenea & 3.30 & 184.20 & 0.005 & $\mathrm{BD} 3>\mathrm{BD} 1$ \\
\hline Gammarus pulex & 76.20 & 387.30 & 0.005 & $\mathrm{BD} 3>\mathrm{BD} 1$ \\
\hline Hydropsyche siltalai & 0.00 & 76.00 & 0.012 & $\mathrm{BD} 3>\mathrm{BD} 1$ \\
\hline Polycelis felina & 0.10 & 101.70 & 0.002 & $\mathrm{BD} 3>\mathrm{BD} 1$ \\
\hline \multirow[t]{2}{*}{ Silo pallipes } & 0.00 & 22.60 & 0.010 & $\mathrm{BD} 3>\mathrm{BD} 1$ \\
\hline & F41 & F43 & & \\
\hline Theodoxus fluviatilis & 61.40 & 14.60 & 0.004 & $\mathrm{~F} 41>\mathrm{F} 43$ \\
\hline Oligochaeta & 2132.80 & 552.60 & 0.007 & $\mathrm{~F} 41>\mathrm{F} 43$ \\
\hline \multirow[t]{2}{*}{ Baetis rhodani } & 9.70 & 33.80 & 0.043 & $\mathrm{~F} 43>\mathrm{F} 41$ \\
\hline & F51 & F53 & & \\
\hline Baetis buceratus & 25.17 & 6.08 & 0.008 & $\mathrm{~F} 51>\mathrm{F} 53$ \\
\hline Physa fontinalis & 25.83 & 5.50 & 0.028 & $\mathrm{~F} 51>\mathrm{F} 53$ \\
\hline \multirow[t]{2}{*}{ Athripsodes cinereus } & 7.00 & 13.00 & 0.036 & F53 > F51 \\
\hline & F43 & F53 & & \\
\hline Ancylus fluviatilis & 2.50 & 25.60 & 0.016 & $\mathrm{~F} 53>\mathrm{F} 43$ \\
\hline Athripsodes cinereus & 47.80 & 14.40 & 0.029 & $\mathrm{~F} 43>\mathrm{F} 53$ \\
\hline
\end{tabular}

sediment carried by the stream is low in nutrients and carries no pesticides. The disentanglement of excess sediment impacts from these other land-use effects can provide insights into the specific effects of fine sediment accumulation [43]. It is likely therefore that in our study, that the main effects of the sediment will be mechanical damage during spates and clogging of interstitial spaces in the substratum. Armitage and Blackburn [46] compared the fauna of Bovington Stream with that of the adjacent Holy Stream whose catchment was undisturbed and found only one specimen of filter feeding Simuliidae in the former stream. The composition of the suspended sediment in Bovington Stream is mainly colloidal and clay [41] and this is known to interfere with feeding in Simuliidae $[47,48]$. Within CoFSI, Simuliidae taxa are scored 

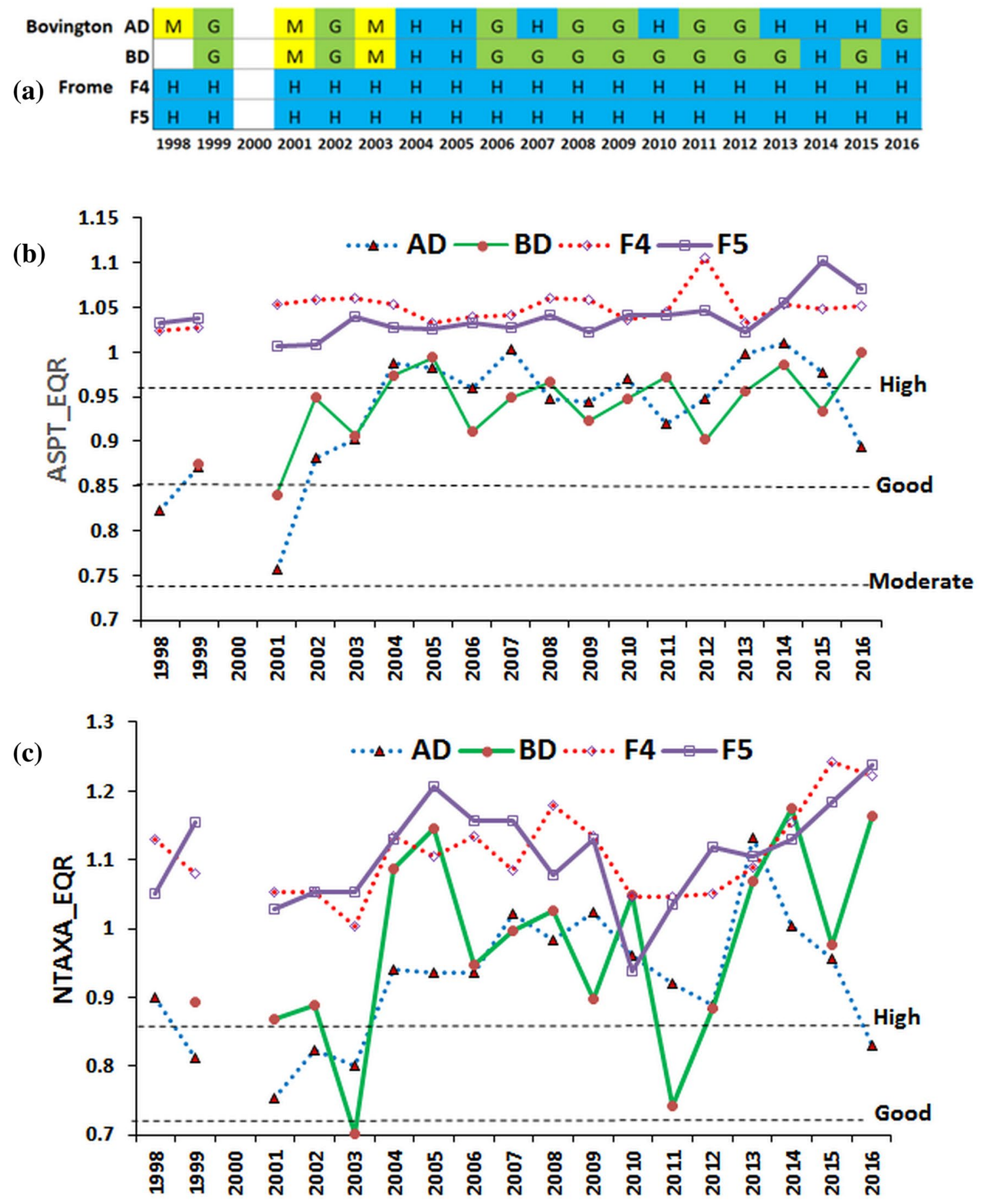

Fig. 4 (a) Overall classification of ecological status for all sites in all years based on the lower of the NTAXA and ASPT classes. $\mathrm{H}=$ High, $\mathrm{G}=$ Good, $M=$ Moderate. Ecological Quality Ratios (EQRs) for (b) ASPT and (c) NTaxa. The banding of the EQRs into quality classes is

as being sensitive or very sensitive to fine sediment [40]. Numbers of Simuliidae are still relatively low (1-2 larvae per sample) but they now are consistently found at both Bovington Stream sites, while before 2009 they were only represented by dashed lines. Sites that fall below the 'good' quality threshold (solid horizontal line) are deemed to be failing ecological quality targets. No data available for 2000 or for 1998 at BD

intermittently recorded, suggesting an easing of sediment pressure.

Despite the installation of the diversion pond and channel between sites $A D$ and $B D$, they had similar 

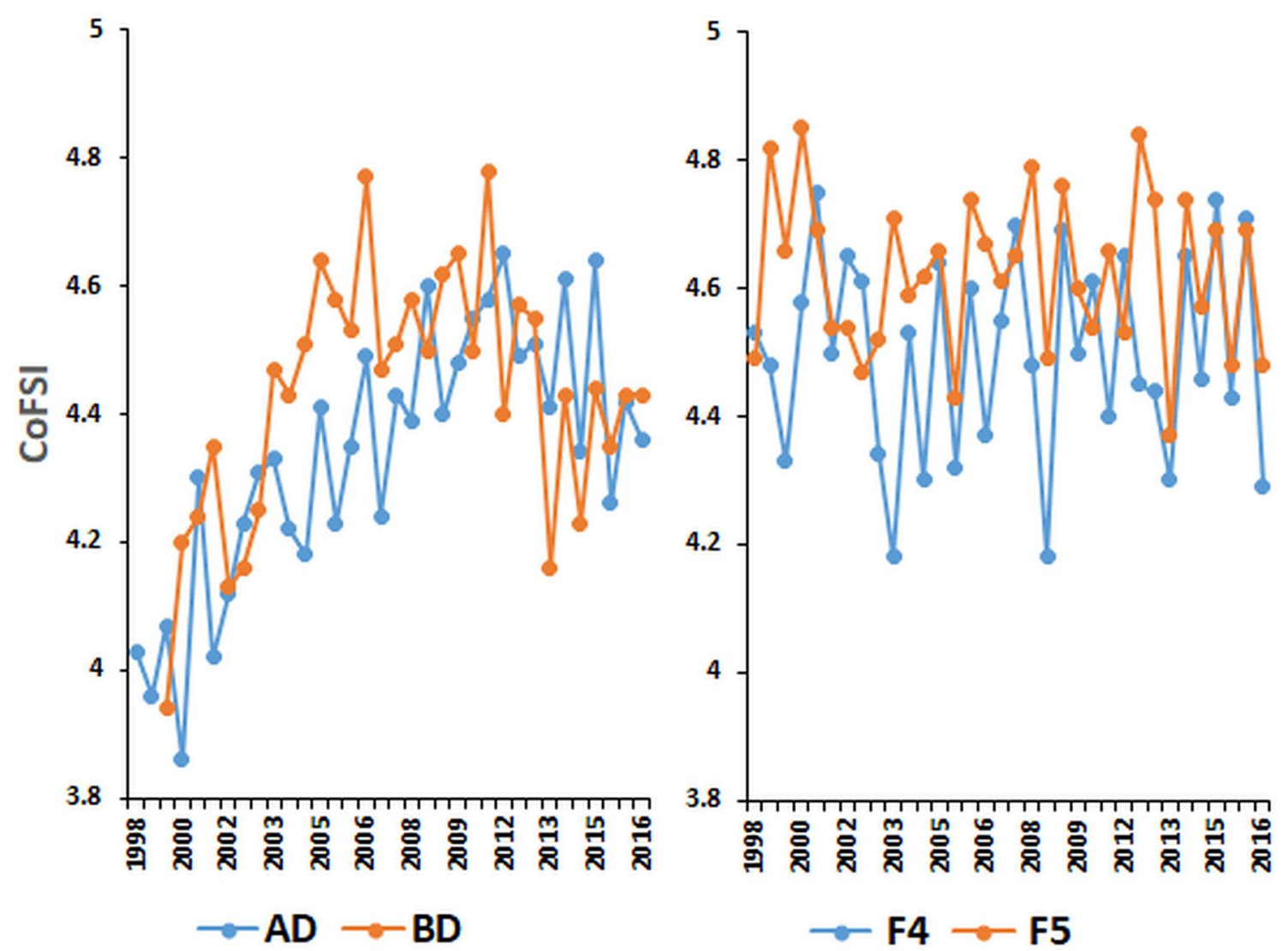

Fig. 5 CoFSI scores of fine sediment impact for the Frome and Bovington study sites from 1998 to 2016. NB: no data available for 2000

communities both at the start and end of the study. However, there was an indication that abundances of some taxa were greater below the diversion pond e.g. A. fluviatilis, G. pulex, L. volckmari and E. aenea; all of which are tolerant of low organic content fine sediment in the stream bed [40]. Overall abundance was not significantly different between sites or year groups.

\subsection{Sediment management}

The CoFSI index employed in this study has shown that the sediment management strategies have succeeded in reducing fine sediment impacts to the Bovington Stream. In a wider context CoFSI was developed from a calibration dataset of 230 sites across the England and Wales selected to represent the full range from very high to very low fine sediment pressure. This pressure gradient reflects catchment geology, topography and land use [49], which all have an impact on the load of fine sediment delivered to rivers. Across this calibration dataset, the CoFSI scores returned for individual sites varied between 3 and 6 , with higher scores indicating very low pressure from fine sediment, typically high gradient streams draining upland catchments. Hence, the results for the Frome and
Bovington sites, suggest some degree of fine sediment deposition on the riverbed, which is inevitable for lowland river catchments.

Particle size is the most important physical characteristic in controlling the transport and geochemical dynamics of suspended sediment. It is evident that although the loading of coarse sediment has decreased at BD, the absence of flushing flows has allowed fine sediment to accumulate on the substratum and this may account for the lower CoFSI scores recorded towards the end of the study period. The observed differences between $A D$ and $B D$ may be due to these perceived sediment differences and their effects on the benthos but as Wood et al. [50] noted, the response of individual taxa is very variable and we need considerably more information on responses of specific taxa.

The methods employed by the MOD to control the mobilisation of sediment in the upper catchment have, as indicated by the continued high quality of the Frome and improvements in the Bovington Stream, been successful. The original plan in the lower catchment was that high flows exceeding the diversion channel's capacity would overflow thus depositing sediment in the surrounding woodland. This solution was deemed unacceptable due 
to land-use issues and the diversion channel was therefore enlarged to accommodate high flows which run unimpeded into the settlement pond, where sediment drops out of suspension. Despite this missed opportunity to trap sediment on the woodland floor our results have shown significant improvements in the ecological quality of the Bovington Stream. However, continued success depends on the regular maintenance of dams, emptying of silt ponds and regular inspection of silt traps in the catchment. In addition, the pipes draining the Diversion Pond should be cleaned out regularly to ensure sufficient flow to maintain the benthic community at Site BD and further downstream to the confluence with the R. Frome.

Despite the improvements in ecological quality there is still a visual impact of sediment in the Frome. This is because most of the sediment is clay and does not settle out. This raises the issue of public perception of 'pollution' versus actual impacts [51]. The Frome is a chalk stream and usually associated with clear non turbid water under normal flow conditions, so any discolouration is very noticeable. Tocher [41] showed that the two clay minerals (illite and kaolinite) characteristic of the upper Bovington Stream sediment were absent from the Frome bed sediment downstream of the confluence, thus indicating no deposition. The settlement ponds were ineffective at removing the finer fractions of the suspended sediment probably due to the very low velocities required to keep clay-sized particles entrained and the relatively small surface area of the main settlement pond ( $0.33 \mathrm{ha}$ ). The inefficiency of the pond to remove suspended fines is compounded by the check dams in the upper catchment which act as a store of fine sediment. The required area of a sedimentation basin can be calculated for a number of typical pond or wetland shapes [52,53] and Tocher [41] calculated that the main settlement pond in the lower catchment of the Bovington Stream should be 4.3 ha for maximum removal of finer sediment and clays.

At the start of the study the most noticeable contributor to discolouration of the River Frome was output from the Bovington Stream [31]. However, at the end of the study, a tributary about $600 \mathrm{~m}$ upstream of the Bovington/Frome confluence, the River Win, which drains an agricultural catchment [18] showed a greater visual impact than Bovington Stream. This provides some additional evidence that remediation measures in the Bovington catchment are reducing sediment loading into the Frome.

\subsection{Wider implications}

Long-term ecological studies are critical for providing key insights into environmental change, natural resource management and biodiversity conservation [54]. They have particular relevance in problems associated with excess sediment in rivers since those problems are associated with catchment land-use and activities within a single catchment may range widely over the years. Only a longterm study will provide data and understanding of the impacts at scales relevant to management. Early ecologists recognised that the duration of a study may significantly influence the conclusions drawn from it [55]. In our study we were able to detect an initial response to the sediment remediation measures but repeated sampling over the years showed that the initial positive response was reduced slightly. In a shorter study this response would not have been noted. Information like this can provide useful feedback to managers. In addition, the long period of sampling has provided information on the magnitude of natural temporal change in the faunal community of the River Frome at both sites above and below the inflow of the Bovington Stream.

This combination of extended standardised monitoring in conjunction with the use of an index of sediment stress, we believe has wide applicability. Firstly, most of the sediment control strategies in the upper catchment are simple and easily maintained. The most expensive element being the construction of an all-weather track, an essential element because unpaved roads/tracks are a major factor in erosion and sediment generation in military training areas [8]. Secondly, the simple and relatively inexpensive monitoring programme could be repeated without stretching limited budgets thus producing a long-term data set for future applications. Thirdly, the information from the faunal responses can help managers plan the timing and extent of effective mitigation measures.

\section{Conclusions}

1. Significant community changes occurred in the Bovington Stream but none in the Frome over the 19-year period.

2. Most change in the Bovington Stream occurred in the first six years with increases in taxon richness and Ecological Quality.

3. We can be confident from our knowledge of the catchment that there have been no substantial land-use changes or extreme events which would impact the river other than the sediment remediation work and conclude that the observed 'improvements' in the Bovington Stream are in large part due to the sediment control management undertaken by the Ministry of Defence.

4. Discolouration of the receiving waters of the Frome from suspended clay particles is still evident and an enlargement of the wetland settlement pond is suggested to ameliorate this problem. 
Acknowledgments We are most grateful to Major George Preston who was the driving force behind the initial investigations and the late John Blackburn for his invaluable taxonomic skills in the early years of the project from 1998 to 2004 and to our colleagues (C Duerdoth, N Kneebone, I Harris, $\mathrm{H}$ Vincent and R Wiggers) for their assistance in the field and laboratory. The work has been funded since 1998 by a series of grants provided by Defence Infrastructure Organisation. The Environment Agency provided data on both water courses. We are grateful to the three anonymous reviewers who provided helpful comments that greatly improved the quality of the manuscript.

\section{Compliance with ethical standards}

Conflict of interest The authors declare that they have no conflict of interest.

\section{Appendix: Between year group abundances with $95 \%$ confidence limits (CL) for taxa contributing $>0.5 \%$ to the total at each site}

\begin{tabular}{|c|c|c|c|c|c|c|c|c|c|c|c|c|}
\hline \multicolumn{13}{|c|}{ (a) Bovington Stream sites AD and BD } \\
\hline & AD1 & $C L$ & AD2 & $\mathrm{CL}$ & AD3 & $C L$ & BD1 & $C L$ & BD2 & $C L$ & BD3 & $C L$ \\
\hline $\begin{array}{l}\text { Potamopyrgus } \\
\text { antipodarum }\end{array}$ & 634 & 417 & 603 & 345 & 519 & 386 & 548 & 353 & 146 & 146 & 257 & 227 \\
\hline Gammarus pulex & 64 & 48 & 171 & 51 & 180 & 148 & 76 & 63 & 473 & 208 & 365 & 150 \\
\hline Oligochaeta & 387 & 405 & 56 & 20 & 45 & 16 & 282 & 436 & 54 & 47 & 41 & 30 \\
\hline Limnius volckmari & 45 & 23 & 102 & 31 & 114 & 48 & 127 & 122 & 250 & 111 & 212 & 58 \\
\hline Elmis aenea & 2 & 2 & 76 & 36 & 81 & 39 & 3 & 2 & 248 & 106 & 186 & 86 \\
\hline $\begin{array}{l}\text { Hydropsyche angusti- } \\
\text { pennis }\end{array}$ & 49 & 34 & 26 & 11 & 6 & 2 & 49 & 32 & 93 & 46 & 15 & 7 \\
\hline Ancylus fluviatilis & 40 & 17 & 15 & 11 & 13 & 7 & 55 & 41 & 40 & 27 & 37 & 22 \\
\hline Baetis rhodani & 1 & 1 & 35 & 21 & 22 & 14 & 5 & 5 & 57 & 27 & 30 & 16 \\
\hline Polycelis felina & 0 & 0 & 7 & 3 & 2 & 1 & 0 & 0 & 23 & 8 & 93 & 46 \\
\hline Hydropsyche siltalai & 0 & 0 & 13 & 17 & 21 & 12 & 0 & 0 & 14 & 13 & 75 & 43 \\
\hline Nemoura avicularis & 31 & 41 & 10 & 8 & 28 & 33 & 15 & 14 & 2 & 2 & 8 & 6 \\
\hline Silo pallipes & 0 & 0 & 20 & 18 & 13 & 7 & 0 & 0 & 22 & 20 & 21 & 13 \\
\hline Asellus aquaticus & 12 & 9 & 4 & 2 & 5 & 4 & 28 & 23 & 7 & 5 & 9 & 6 \\
\hline Ephemera danica & 7 & 8 & 13 & 7 & 7 & 3 & 7 & 3 & 11 & 4 & 20 & 9 \\
\hline Orthocladiinae & 16 & 15 & 4 & 3 & 4 & 2 & 10 & 8 & 12 & 9 & 15 & 12 \\
\hline Sphaeriidae & 15 & 13 & 4 & 2 & 9 & 5 & 4 & 3 & 1 & 0 & 23 & 23 \\
\hline Dicranota sp. & 3 & 4 & 19 & 14 & 10 & 6 & 2 & 4 & 11 & 5 & 8 & 3 \\
\hline $\begin{array}{l}\text { Glossiphonia compla- } \\
\text { nata }\end{array}$ & 7 & 5 & 8 & 3 & 7 & 5 & 11 & 8 & 6 & 2 & 5 & 4 \\
\hline Tanytarsini & 2 & 3 & 0 & 0 & 2 & 2 & 5 & 4 & 7 & 6 & 23 & 33 \\
\hline $\begin{array}{l}\text { Sericostoma perso- } \\
\text { natum }\end{array}$ & 0 & 0 & 8 & 6 & 8 & 5 & 4 & 4 & 8 & 3 & 11 & 5 \\
\hline$\%$ contribution & 97 & & 96 & & 96 & & 97 & & 97 & & 95 & \\
\hline \multicolumn{13}{|c|}{ (b) River Frome sites F4 and F5 } \\
\hline & F41 & $\mathrm{CL}$ & F42 & $C L$ & F43 & $C L$ & F51 & $\mathrm{CL}$ & F52 & $C L$ & F53 & $\mathrm{CL}$ \\
\hline Oligochaeta & 1874 & 857 & 584 & 357 & 553 & 299 & 402 & 273 & 250 & 196 & 505 & 232 \\
\hline Gammarus pulex & 310 & 85 & 140 & 57 & 959 & 710 & 533 & 648 & 399 & 229 & 1396 & 567 \\
\hline $\begin{array}{l}\text { Brachycentrus sub- } \\
\text { nubilus }\end{array}$ & 87 & 74 & 37 & 24 & 350 & 341 & 155 & 312 & 48 & 25 & 353 & 296 \\
\hline Sphaeriidae & 379 & 239 & 185 & 87 & 170 & 153 & 7 & 140 & 26 & 23 & 18 & 11 \\
\hline Orthocladiinae & 48 & 34 & 30 & 24 & 126 & 128 & 47 & 117 & 30 & 20 & 147 & 124 \\
\hline Elmis aenea & 19 & 7 & 18 & 7 & 90 & 78 & 45 & 71 & 45 & 28 & 203 & 151 \\
\hline $\begin{array}{l}\text { Aphelocheirus aes- } \\
\text { tivalis }\end{array}$ & 102 & 43 & 56 & 26 & 57 & 27 & 59 & 24 & 43 & 29 & 41 & 23 \\
\hline Chironomini & 66 & 28 & 38 & 17 & 49 & 34 & 47 & 31 & 13 & 8 & 100 & 130 \\
\hline
\end{tabular}


(b) River Frome sites F4 and F5

\begin{tabular}{|c|c|c|c|c|c|c|c|c|c|c|c|c|}
\hline & F41 & $\mathrm{CL}$ & F42 & $\mathrm{CL}$ & F43 & $\mathrm{CL}$ & F51 & $\mathrm{CL}$ & F52 & $\mathrm{CL}$ & F53 & $\mathrm{CL}$ \\
\hline Limnius volckmari & 14 & 7 & 9 & 5 & 26 & 23 & 85 & 21 & 35 & 19 & 99 & 58 \\
\hline Theodoxus fluviatilis & 56 & 19 & 31 & 9 & 15 & 9 & 71 & 8 & 38 & 11 & 55 & 32 \\
\hline Ephemera danica & 31 & 13 & 32 & 25 & 104 & 86 & 10 & 78 & 20 & 19 & 63 & 45 \\
\hline Baetis rhodani & 9 & 5 & 16 & 18 & 34 & 20 & 25 & 19 & 42 & 14 & 76 & 54 \\
\hline $\begin{array}{l}\text { Hydropsyche pel- } \\
\text { lucidula }\end{array}$ & 15 & 5 & 9 & 6 & 51 & 40 & 22 & 36 & 13 & 6 & 86 & 57 \\
\hline Ithytrichia sp. & 46 & 37 & 32 & 18 & 30 & 42 & 34 & 39 & 46 & 30 & 7 & 7 \\
\hline Athripsodes cinereus & 36 & 18 & 37 & 15 & 48 & 26 & 7 & 24 & 19 & 12 & 13 & 10 \\
\hline Radix balthica & 3 & 2 & 5 & 3 & 37 & 29 & 14 & 26 & 18 & 19 & 49 & 51 \\
\hline Heptagenia sulphurea & 20 & 12 & 11 & 4 & 56 & 68 & 11 & 62 & 12 & 4 & 15 & 8 \\
\hline Baetis buceratus & 17 & 8 & 10 & 6 & 7 & 6 & 25 & 6 & 44 & 28 & 6 & 3 \\
\hline Physa fontinalis & 38 & 29 & 18 & 13 & 8 & 10 & 26 & 9 & 11 & 14 & 6 & 6 \\
\hline $\begin{array}{l}\text { Potamopyrgus antipo- } \\
\text { darum }\end{array}$ & 3 & 4 & 1 & 1 & 6 & 5 & 7 & 5 & 2 & 3 & 75 & 128 \\
\hline Bithynia tentaculata & 20 & 15 & 28 & 11 & 11 & 8 & 5 & 8 & 15 & 8 & 5 & 3 \\
\hline $\begin{array}{l}\text { Simulium ornatum } \\
\text { group }\end{array}$ & 4 & 3 & 10 & 18 & 6 & 5 & 28 & 5 & 17 & 7 & 13 & 12 \\
\hline $\begin{array}{l}\text { Hydropsyche contu- } \\
\text { bernalis }\end{array}$ & 11 & 6 & 7 & 4 & 9 & 9 & 13 & 8 & 11 & 7 & 21 & 15 \\
\hline Asellus aquaticus & 9 & 6 & 14 & 11 & 11 & 8 & 10 & 7 & 20 & 27 & 9 & 5 \\
\hline Tanytarsini & 13 & 12 & 5 & 4 & 38 & 56 & 5 & 51 & 1 & 1 & 8 & 10 \\
\hline Ostracoda & 23 & 31 & 9 & 7 & 10 & 12 & 1 & 11 & 8 & 14 & 1 & 1 \\
\hline Ancylus fluviatilis & 4 & 3 & 0 & 0 & 3 & 2 & 12 & 1 & 7 & 5 & 23 & 13 \\
\hline Hydropsyche siltalai & 0 & 0 & 0 & 0 & 5 & 5 & 2 & 5 & 1 & 1 & 40 & 28 \\
\hline$\%$ contribution & 94 & & 89 & & 93 & & 91 & & 88 & & 94 & \\
\hline
\end{tabular}

\section{References}

1. Vercruysse K, Grabowski RC, Rickson RJ (2017) Suspended sediment transport dynamics in rivers: multi-scale drivers of temporal variation. Earth Sci Rev 166:38-52. https://doi.org/10.1016/j. earscirev.2016.12.016

2. Hauer C, Leitner P, Unfer G, Pulg U, Habersack H, Graf W (2018) The role of sediment and sediment dynamics in the aquatic environment. In: Schmutz S, Sendzimir J (eds) Riverine ecosystem management, Aquatic Ecology Series 8, https://doi. org/10.1007/978-3-319-73250-3_8

3. Morgan RPC (2005) Soil erosion and conservation. Blackwell Publishing Ltd, Oxford, p 304

4. Minella JPG, Walling DE, Merten GH (2014) Establishing a sediment budget for a small agricultural catchment in southern Brazil, to support the development of effective sediment management strategies. J Hydrol 519:2189-2201. https://doi. org/10.1016/j.jhydrol.2014.10.013

5. Nerbonne B, Vondracek B (2001) Effects of local land use on physical habitat, benthic macroinvertebrates, and fish in the Whitewater River, Minnesota, USA. Environ Manag 28:87-99. https://doi.org/10.1007/s002670010209

6. Stewart C, Gabrielsson R, Shearer K, Holmes R (2019) Agricultural intensification, declining stream health and angler use: a case example from a brown trout stream in Southland, New Zealand. N Z Nat Sci 44:1-10
7. Nuttall P (1972) The effect of sand deposition upon the macroinvertebrate fauna of the River Camel, Cornwall. Freshw Biol 2:181-186

8. Byrne PA, Wood PJ, Reid I (2011) The impairment of river systems by metal mine contamination: a review including remediation options. Crit Rev Environ Sci Technol 42:2017-2077 ISSN 1064-3389

9. Béjar M, Gibbins CN, Vericat D, Batalla RJ (2017) Effects of suspended sediment transport on invertebrate drift. River Res Appl 33:1655-1666. https://doi.org/10.1002/rra.3146

10. Maloney KO, Mulholland P, Feminella JW (2005) Influence of catchment-scale military land use on stream physical and organic matter variables in small Southeastern Plains Catchments (USA). Environ Manag 35:677-691. https://doi. org/10.1007/s00267-004-4212-6

11. Cook TL, Snyder NP, Wyatt Oswald W, Paradis K (2020) Timber harvest and flood impacts on sediment yield in a postglacial, mixed-forest watershed, Maine, USA. Anthropocene 29:1-15. https://doi.org/10.1016/j.ancene.2019.100232

12. Sear DA (1995) Morphological and sedimentological changes in a gravel-bed river following 12 years of flow regulation for hydropower. Regul Rivers Res Manage 10:247-264. https://doi. org/10.1002/rrr.3450100219

13. Paul MJ, Meyer JL (2001) Streams in the Urban landscape. Annu Rev Ecol Syst 32:333-365

14. Wood PJ, Armitage PD (1997) Biological effects of fine sediment in the lotic environment. Environ Manag 21:203-217 
15. Jones Jl, Murphy JF, Collins AL, Sear DA, Naden PS, Armitage PD (2012) The impact of fine sediment on macro-invertebrates. River Res Appl 28:1055-1071

16. Collins AL, Zhang Y (2016) Exceedance of modern 'background' fine-grained sediment delivery to rivers due to current agricultural land use and uptake of water pollution mitigation options across England and Wales. Environ Sci Pol 61:61-73. https://doi. org/10.1016/j.envsci.2016.03.017

17. Pearson C (2015) Effects of agricultural intensification on the ecology of upland stream invertebrate communities. Dissertation, University of Cardiff

18. Armitage PD, Bass JAB, Murphy JF, Tapia G (2018) A comparison of the freshwater invertebrate communities of the River Win (Dorset) present in 1993 and 2016, over a period with agricultural intensification across the catchment. Proc Dorset Nat Hist Archeol Soc 139:72-82

19. Ohio Department of Transportation (2000) Handbook for sediment and erosion control, $73 \mathrm{pp}$

20. Berry L, Olson J, Campbell D (2003) Assessing the extent, cost and impact of land degradation at the National Level: findings and Lessons Learned from Seven Pilot Countries. Photocopy. Paper commissioned by the Global Mechanism of the UN Commission to Combat Desertification. Global Mechanism of the UNCCD, Rome

21. Brils J (2008) Sediment monitoring and the European Water Framework Directive. Ann Ist Super Sanita 44:218-223

22. Boardman J, Vandaele K (2020) Managing muddy floods: balancing engineered and alternative approaches. J Flood Risk Manag 13:e12578. https://doi.org/10.1111/jfr3.12578

23. Louhi P, Mykrä H, Paavola R, Huusko A, Vehanen T, Mäki-Petäys $A$, Muotka T (2011) Twenty years of stream restoration in Finland: little response by benthic macroinvertebrate communities. Ecol Appl 21:1950-1961. https://doi.org/10.1890/10-0591.1

24. Bradley DC, Ormerod SJ (2001) Community persistence among stream invertebrates tracks the North Atlantic Oscillation. J Anim Ecol 70:987-996

25. Chessman BC (2009) Climatic changes and 13-year trends in stream macroinvertebrate assemblages in New South Wales, Australia. Glob Chang Biol 15:2791-2802. https://doi.org/10.1 $111 / \mathrm{j} .1365-2486.2008 .01840 . x$

26. Durance I, Ormerod SJ (2009) Trends in water quality and discharge confound long-term warming effects on river macroinvertebrates. Freshw Biol 54:388-405. https://doi.org/10.111 1/j.1365-2427.2008.02112.x

27. Lawrence JE, Junde KB, Mazor RD, Bêche LA, McElravy EP (2010) Long-term macroinvertebrate response to climate change: implications for biological assessment in Mediterranean-climate streams. J N Am Benthol Soc 29:1424-1440. https://doi. org/10.1899/09-178.1

28. Van Looy K, Floury M, Ferréol M, Prieto-Montes MM, Souchon $Y$ (2016) Long-term changes in temperate stream invertebrate communities reveal a synchronous trophic amplification at the turn of the millennium. Sci Total Environ 565:481-488

29. Swank WT, Webster JR (eds) (2014) Long-term response of a forest watershed ecosystem. Clearcutting in the Southern Appalachians. Oxford University Press, New York, p 10016

30. Preston G (2005) A surfeit of silt. Sanctuary $34: 56 \mathrm{https} / / /$ asset s.publishing.service.gov.uk/government/uploads/system/uploa ds/attachment_data/file/33357/sanctuary_34.pdf

31. Armitage PD (2005) Sediment on the move- Tank training and stream life. Sanctuary 34:57-59 https://assets.publishing.servi ce.gov.uk/government/uploads/system/uploads/attachment data/file/33357/sanctuary_34.pdf

32. Environment Agency (2003) River habitat survey in Britain and Ireland: field survey guidance manual river habitat survey manual, 2003 version. Environment Agency, Bristol, p 136
33. Environment Agency (2011) Standing Committee of Analysts (SCA library): methods for the examination of waters and associated material - Index of methods for the examination of waters and associated materials 1976-2011 blue book 236. http://www. standingcommitteeofanalysts.co.uk

34. Leach D, Henville P, Wyatt R, Hewitt E, Morrissey I, Weller J, Tindall Cl, Bachiller-Jareno N (2015) Continuous measurements of conductivity, dissolved oxygen, $\mathrm{pH}$, temperature and water level in rivers (2002-2007) [LOCAR]. NERC Environmental Information Data Centre. https://doi.org/10.5285/00895096-e083-498f9a52-b7f9e3291125

35. Mann HB (1945) Nonparametric tests against trend. Econometrica 13:245-259

36. Clarke KR, Warwick RM (2001) Change in marine communities: an approach to statistical analysis and interpretation, 2nd edn. PRIMER-E Ltd Plymouth Marine Laboratory, Plymouth

37. McLeod Al (2011) Kendall: Kendall rank correlation and MannKendall trend test. R Package Version 2.2, http://CRAN.R-proje ct.org/package $=$ Kendall

38. R Development Core Team (2019) R: A language and environment for statistical computing. R foundation for statistical computing, Vienna, Austria, ISBN 3-900051-07-0, http://www.R-proje ct.org

39. Davy-Bowker J, Clarke R, Corbin T, Vincent H, Pretty J, Hawczak A, Blackburn J, Murphy J, Jones I (2008) River invertebrate classification tool. Final Report. Scotland and Northern Ireland Forum for Environmental Research (SNIFFER), Edinburgh, p 268 (SNIFFER Project WFD72C, CEH Project Number: C02404). http:// eprints.bournemouth.ac.uk/16550/2/SNIFFER_WFD72C_RICT_ Final_Report_-_Davy-Bowker\%2C_Clarke_et_al_2008.pdf

40. Murphy JF, Jones JI, Pretty JL, Duerdoth CP, Hawczak A, Arnold A, Blackburn JH, Naden PS, Old G, Sear DA, Hornby D, Collins AL (2015) Development of a biotic index using stream macroinvertebrates to assess stress from deposited fine sediment. Freshw Biol 60:2019-2036

41. Tocher J (2004) Tank training and river habitat: tracing sediment deposition in a river system. Dissertation Royal Holloway University of London, $83 \mathrm{pp}$

42. Kondolf G (1997) PROFILE: hungry water: effects of dams and gravel mining on river channels. Environ Manag 21:533-551. https://doi.org/10.1007/s002679900048

43. Matthaei CD, Weller F, Kelly DW, Townsend CR (2006) Impacts of fine sediment addition to tussock, pasture, dairy and deer farming streams in New Zealand. Freshw Biol 51:2154-2172. https:// doi.org/10.1111/j.1365-2427.2006.01643.x

44. Russell KL, Vietz GJ, Fletcher TD (2017) Global sediment yields from urban and urbanizing watersheds. Earth Sci Rev 168:73-80. https://doi.org/10.1016/j.earscirev.2017.04.0016

45. Jordan MM (2019) Historical floodplain sedimentation rates using mining contaminant profiles, cesium-137, and sediment source indicators along the Lower Big River, Jefferson County, Missouri. Dissertation, Missouri State University. https://bearw orks.missouristate.edu/theses/3408

46. Armitage PD, Blackburn JH (2001) The macroinvertebrate fauna of the Holy Stream, a small tributary of the River Frome, Dorset. Proc Dorset Nat Hist Archeol Soc 123:95-100

47. Kurtak DC (1978) Efficiency of filter feeding of black fly larvae (Diptera Simuliidae). Can J Zool 56:1608-1623

48. Gaugler R, Molloy D (1980) Feeding inhibition in black fly larvae (Diptera, Simuliidae) and its effects on the pathogenicity of Bacillus thuringiensis var israelensis. Environ Entomol 9:704-708

49. Collins AL, Anthony SG, Hawley J, Turner T (2009) The potential impact of projected change in farming by 2015 on the importance of the agricultural sector as a sediment source in England and Wales. Catena 79:243-250. https://doi.org/10.1016/j.caten a.2009.05.007 
50. Wood PJ, Toone J, Greenwood MT, Armitage PD (2005) The response of four lotic macroinvertebrate taxa to burial by sediments. Arch Hydrobiol 163(2):145-162

51. Okumah M, Yeboah AS, Bonyah SK (2020) What matters most? Stakeholders' perceptions of river water quality. Land Use Policy 99:1-13. https://doi.org/10.1016/j.landusepol.2020.104824

52. Wong THF, Fletcher D, Duncan HP, Coleman JR, Jenkins GA (2002) A Model for Urban Stormwater Improvement Conceptualisation. Int Cong Environ Model Softw 122:48-53 https://schol arsarchive.byu.edu/iemssconference/2002/all/122

53. Koskiaho J (2003) Flow velocity retardation and sediment retention in two constructed wetland-ponds. Ecol Eng 19:325-337. https://doi.org/10.1016/S0925-8574(02)00119-2
54. Lindenmayer DB, Likens GE, Andersen A, Bowman D et al (2012) Value of long-term ecological studies. Austral Ecol 37:745-757. https://doi.org/10.1111/j.1442-9993.2011.02351.x

55. Jackson JK, Füreder L (2006) Long-term studies of freshwater macroinvertebrates: a review of the frequency, duration and ecological significance. Freshw Biol 51:591-603. https://doi.org /10.1111/j.1365-2427.2006.01503.x

Publisher's Note Springer Nature remains neutral with regard to jurisdictional claims in published maps and institutional affiliations. 